\title{
Symbolism in William Blake's poem Tyger
}

Umapati Neupane*

\begin{abstract}
This is a preliminary study that attempts to define symbol with its background and its movement in English literature. It is a research-based article. This study explores symbolism in William Blake's poem a Tyger. It also describes how different kinds of symbols are used to creating denotative and connotative meanings of the poem. In poetry, symbols are usually images with conventional meaning. In order to justify the objective, the poet makes a partial analogy between images and ideas. The whole poem stands only in symbolic relation with life and reality. The study addresses poet's philosophy of composing such symbolic poem. This study examines the different kinds of symbols used in his poem.
\end{abstract}

Keywords: Innocence, experience, ignorance, sense of wonder, creativity, imagination, symbol, spiritual revolution

\section{Introduction:}

This poem is taken from the end of the second part of the book Songs of Innocence and Songs of Experience. In the first part, the poet describes child's world of innocence where things, people, society, religion and human nature are natural and unspoilt. But the second part is about the adult world of corruption. The king, priest and landlord have polluted the naturally good society, religion and culture. People are evil, selfish, cruel, oppressive and sinners. The poem interprets poet's philosophy of symbolic myths about human life, soul, society, spiritual revolution and the world. Most poems have symbolic meanings. The symbol is the most complex metaphorical device of word game. In its simplest sense, it is a comparison between a concrete entity and an abstract idea. Any object, image, event, story or anything that can be interpreted as having broader conceptual meaning outside the literal and contextual meaning is said to be symbolic. In that sense, anything in a poem that must be interpreted in relation to general ideas. In one sense, all words are symbolic because a sound sequence represents an idea of life and reality is also a symbol. The poem describes the world of oppression and evil.
The poet was also a radical social thinker, who hated the king, priest and landlord and blamed them as worms that eat the spirit of common man and pollute their relation with other men with god and nature. He claimed that men still have the tyger- like force of the soul which they can use for fighting against the oppression and darkness of the world of evils. Poet believed that every individual revolts against the systems of the society that darkens the natural brilliance of his spirit and intelligence. He believed that every individual has the natural, spiritual and intellectual powers to know the ultimate truth and spirituality but they lose natural brilliance when they grow up into the world of the artificial systems of politics, religion and culture. The poet sees a tyger before his mind's eye. The tyger has fearful bright eyes. The eyes shine like blazing fire through the thick forest in the dark nights. Therefore, he speaks of the fierce beauty of the tyger. He seems to have lived through bitter days. So, the tyger is poet's symbol for the fierce forces in the soul which are needed to break the bonds of experience. The forest of the night in which the tyger lurks are symbol of ignorance, repression and

*Lecturer, Department of English, Butwal Multiple Campus, Butwal 
superstition. The poem consists of lots of symbols such as tyger is symbol of fierce strength. Tyger's eyes symbolize vision, prophecy and window of the soul. Tyger's shoulders are symbol of enormous strength. Tyger's hands or feet symbolize the skill and hard work. The heart of tyger is symbol of emotion. In the poem, the poet suddenly sees a tyger and starts asking questions about its creator. Symbolically, the poet suddenly begins to realize that there is the force of a tyger in his mind; that is the force of his spirit, creativity, revolutionary and the powerful force of his soul which he can use to fight against the evils of the dark society, and be free. He begins to realize that his God, however, mysterious and unknowable himself, has given him not only the gentleness of the lamb but also the force of a tiger. The very title indicates the unusual spelling of the Tyger that means it is not an ordinary tyger, but a tyger. Secondly, the tyger of this poem is burning, which the real ones never do. Thirdly, the forest which is the habitat of this tyger is not at night but of the night. This means that the forest is made of the night. The night is the material and the forest is its product. Fourthly, it is not the singular forest but plural forests where the tyger burns. Fifthly, the creator of the tyger is also referred to only in terms of hand or eye, which means that it is the creation of someone whose hand and eye are emphasized. The small innocent lamb not only attracts him but also the most dangerous tyger also attracts him. The present poem is precisely about the individual in the dark forest with evils and ignorance; the speaker realizes that there is a tygerlike fierce force in his soul, which he can use to overcome the darkness created by the society in his own mind. The poet is struck by a sense of wonder at the fierce beauty of the tyger. The tyger has so shining bright eyes that they blaze like burning fire in the dim and dark jungles at night. The poet is surprised at this huge shape of the tyger and its burning bright eyes. He finds it difficult to imagine the hands that wrought so fearful a shape as the tyger's. The poet is curious to know from where the fire is stolen, which has been set in the eyes of the tyger. He doesn't know the source of the unearthly fire which traces the heights of the skies and depth of the seas. He feels that the creator of the tyger must have got powerful pair of wings from where he brought the fire that blaze in the eyes of the tyger. The hand that could seize the fire must have some supernatural powers. The creator of the tyger must have had enough physical strength to mould the shape of the heart of the tyger and its complicated mechanism. The creator, who handled the muscular heart of the tyger, must be some divine being. The poet thinks that the creator had first created the heart of the tyger his hand and feet. Perhaps, it is difficult to mould the shape of the heart of the tyger. It must have been a Herculean task for the creator to create the whole body of the tyger. The poet wonders whether the hand, that created the tyger was the same hand: that created the lamb. The poem encompasses a peculiar tone of wonder and sense of excitement at the terrible beauty of the tyger. The note of wonder and excitement naturally develops into a note of mysticism. He is dazed with the supernatural power of the divine creator who wrought such a terrible being into a shape. Thus, the poem presents a vivid impression of a vast creative spirit labouring at elemental furnace and anvil to mould a mortal form adequate to the passion and fierce beauty of the wealth of god and the wild furies of the human spirit. The poet has rendered into powerful expression of the very essence of the tyger. Therefore, the poem contains a peculiar vision of the ferocity of the tyger's form and sense of wonder and terror in the very essence of the poem.

\section{Concept of symbolism}

The word 'symbol' derives from the Greek verb symbolism 'symballein' to throw together and its noun symbol mark emblem, token or sign. It is an object, animate or inanimate, which represents or stands for something else. A symbol is defined as a metaphor in which the vehicle, the image, activity or concept used to represent something else, represents many related things. For examples - Journey is the symbol of life, nature is a spiritual symbol, rose is symbol of love and beauty, flag is a symbol of nationality. Some images used for representing some abstract ideas are called symbols. In some of the poems, all words are symbols. 
There are two types of symbols: Universal and private. Universal symbols present widely shared association between an object and a concept. Darkness and light are the symbols of evil and good, setting sun is the symbol of death, spring is a symbol of rebirth, peacock is a symbol of pride etc are universal symbols whereas private symbols are different from author to author for the reason that poet associates things with something abstract in the conventional way. Actions and gestures are also symbols. Poet can also create private symbols. The symbol requires the readers to be more tactful and resourceful. In poetry, symbols are usually images with conventional meanings. Clay, sky, spring, cupid and dove are some examples of conventional symbols. Symbolist movement began with a group of French writers Charles Baudelaire, Arthur Rimbaud, Paul Valery, Stephane Mallarme and Paul Verlaine. In England and America, poets such as Arthur Symons and Earnest Dawson as well as W.B. Yeats, Ezra Pound, Dylon Thomas, Hart Crane, E.E Cummings, and Wallace Stevens are known major symbolist poets. Major symbolist poets in Germany are Stefen George and Rainer Maria Rieke. Penguin Reference states:

As far as particular objects are concerned, this kind of symbolism is often private and personal and universal. Another kind of symbolism is known as the transcendental. In this kind, concrete images are used as symbols to represent a general of universal ideal world of which the real world is a shadow. Sir Thomas Browne, long before the theories of symbolism were abandoned suggested the nature of these in his magnificent new Platonic phrase: "The sun itself is the dark simulacrum, and light is the shadow of god". (886)

Symbols are distinguished from both allegories and signs. Like symbols, allegories present an abstract idea through more concrete means, but a symbol is an element of a work used to suggest something else whereas an allegory is typically a narrative with two levels of meaning that is used to making a general statement. Allegory transforms the phenomenon into a concept, the concept into an image, but in such a way that the concept always remains bounded in the image. A literary symbol combines an image with a concept. It may be public or private, universal or local.

\section{Portrayal of symbolism}

The Tyger is a highly symbolic poem based on poet's personal philosophy and his symbolic system of spiritual and intellectual revolution by individuals. The speaker in the poem is puzzled at the sight of a tyger at night, and he asks it a series of questions about its fierce appearance and about the creator who made it. But the context and every theory must be interpreted according to poet's philosophy of symbolic myths about human life, society and spiritual revolution. It is necessary to understand each individual symbol. The tyger is a symbol which represents the terrible force in human soul and even the human intelligence, creativity, imagination and sense of rebellion.

Tyger! Tyger! burning bright | In the forests of the night,

What immortal hand or eye | Could frame thy fearful symmetry? (161)

In this wonderful stanza, the poet expresses that the tyger is burning because it is not an ordinary tyger. The forest is the symbol of corrupted social conventions, artificial systems of politics, culture and religion guided by reason, science and satan and that tries to supress the good human potentials. The hand is a symbol of skills and artistry; the eye symbolizes vision, prophecy, sight, creation and window of the soul. Similarly, the night symbolizes ignorance and evil. The context of a person asking questions and getting puzzles at the tyger symbolically represents the final beginning of realization and appreciation of the forces of his own soul. The god about whom the speaker wonders is also the symbol of universal creator. The poem is interpreted in the light of poet's philosophy about the human soul and the world.

In what distant deeps or skies | Burnt the fire of thine eyes?

On what wings dare he aspire? | What the hand dare sieze the fire? (161)

In this stanza the burning bright eyes of the 
tyger charms the poet greatly. He expresses that it must have taken a wide search to find out the bright and burning fire that have been set in the eyes of the tyger. The poet expresses his wonder at the eyes that have a supernatural glow about them. The speaker asks questions in wonder. He wonders where the tyger must have been created. He guesses that it could be in some far away ocean or skies. Its eyes must have burnt in those distant deeps or skies. The creator must be desirous to fly on his strange wings which are the symbols of creative imagination. He must also be a great artist to give that shape to the tyger. In the symbolic sense, the stanza means that the creator must have created the tyger out of the vastness of his imagination, and that he must have been daring in his creative imagination to seize the fire of knowledge. The fire could be an allusion to the mythical character Prometheus who stole the fire of knowledge from heaven to give to human beings. The wings also imply to the daring revolt of Daedalus to fly away from the prison with the help of his art.

And what shoulder, and what art. | Could twist the sinews of thy heart?

And when thy heart began to beat, | What dread hand? And what dread feet? (161)

In this stanza, the poet expresses his sense of wonder at the strong workmanship behind the make up of the tyger because the tyger has a gigantic body. Its heart must be monster-like. The creator of the monstrous heart of the tyger must have had a supernatural strength. The creator must have taken a super human strength to create the framework of tissues. It must have required a divine power to cast the tyger into its shape. The speaker further wonders about the creator of the tyger. He guesses that his shoulders and muscles must have been very powerful. Tyger's shoulders, shape, muscles, the heart, strange hands and feet have very symbolic meaning. The shoulders are symbols of enormous strength; the heart must be symbol of emotion necessary in the creative being. The hand and feet are also the means of skill and hard work needed to create something to frame its terrible swift and slaughterous claws. How human artists could have made so ferocious form. The strong muscles indicate that he must be very strong and powerful. He also guesses that when the heart of the tyger began to beat, the creator must have controlled it with an enormous amount of strength. He must have strange hands and feet. The word art is the symbol of skill. Ross Murfin and Supriya M.Ray have presented: A symbol may thus be defined as a metaphor in which the vehicle-the image, activity or concept used to represent something elserepresents many related things (tenors) or is broadly suggestive. the urn in Keat's Ode on a Grecian Urn (1820) suggests many interrelated concepts including art, truth, beauty and timelessness. Certain poets and groups of poets have especially exploited the possibilities inherent in symbolism; these include the French symbolist poet of the late nineteenth early twentieth centuries. (391)

Symbols can generally be used and understood within their culture. Poets often create their own symbols by setting up a complex but identifiable web of association in their works. As a result, one object, image, person, place or action suggest others, and may ultimately suggest a range of ideas.

What the hammer? what the chain? | In what furnace was thy brain?

What the anvil? what dread grasp | Dare its deadly terrors clasp? (161)

In this stanza, the speaker thinks that the tyger must have wonderful hands or symbolically wonderful skill. Strange hammer, chin, anvil and furnace are symbols of creativity. His brain symbolizes his intelligence. The poet wants to know what kind of hammer and anvil are used by blacksmith God for creating tyger's body. He thinks that the whole-body structure is very unique and strange. He imagines that the tyger has been wrought into a mould in Smithy. A great Smith possessed of supernatural skill and instruments, which must have carved a tyger into a shape. But the poet is struck with a sense of wonder at the enormity of the hammer, the anvil in which it seems to have been processed through. The furnace 
used to heat its limbs, the hammer used to beat the tyger into a shape and the anvil against which the limbs of the tyger have been beaten into shape must have been of abnormal kind. The Smith must be no human being. Therefore, the Smith seems apparently to be a divine God. The poet uses the metaphor of the blacksmith, who forms metal with a hammer, furnace and anvil. Whoever god is, he must be mysterious, strong, creative, imaginative and bold. He also must have visions for creating animals. The poet makes an allusion to the myth of the blacksmith God. M.H. Abrams and Geoffrey Galt Harpham remark:

The modern period, in the decades after world war I, was a notable era of symbolism in literature. Many of the major writers of the period exploit symbols, which are in part drawn from religious and esoteric traditions and in part invented. Some of the works of the age are symbolist in their settings, their agents and their action, as well as in the objects they refer to. Instances of a persistently symbolic procedure occur in lyrics (Yeats' "Byzantium" poems, Dylon Thomas' series of sonnets Altar wise by owl-light). (307)

Different kinds of actions and gestures are also symbolic. The clenched fist symbolizes aggression. Beating of the breast signifies remorse. Arms raised symbolizes surrender, terrors symbolize danger, hammer symbolizes creativity.

When the stars threw down their spears, | And watered heaven with their tears,

Did he smile his work to see? | Did he who made the Lamb make thee? (161)

In this stanza, the stars symbolize traditional angels who are afraid of rebellious, creative and intellectual spirit. Moreover, the stars are the symbols and agents of reasons, law and order. The speaker thinks when the mysterious god created the tyger, the stars of heaven were so much scared. The poet has been greatly moved by the tragic look of the beast and its fearful symmetry. The tyger is a ferocious animal. It excites a sense of wonder and awe among the beholders. According to the myth, stars also watered the heaven with tears and ran away in fear leaving their spears behind. The speaker also wonders whether the same god who made the gentle lamb also made the fierce tyger. The two present a marked contrast. The lamb stands as a symbol of purity, simplicity, quality of gentleness and stands for Christ too whereas, the tyger is symbolic of a fierce strength, beastly cruelty. The wonder is how could God who created lamb created the tyger. The conventional sources of power that control the society are always scared of the free thinkers, the revolutionary and imaginative artist. Therefore, the speaker has got not only the lamblike gentleness but also the tyger-like forces that he can use against the domination, oppression, discrimination, his free mind and soul. Chris Baldick expresses:

Objects like flags and crosses can function symbolically and words are also symbols. In the semiotics of C.S. Peirce, the term denotes a kind of sign that has no natural connection with its referent, only a conventional one; this is the case with words. In literary uses, however, a symbol is a specially evocative kind of image that is a word or phrase referring to a concrete object, scene, or action which also has some further significance associated with it: roses, mountains, birds and voyages have all been used as common literary symbols. (326) In this sense, all objects, words, images and signs can function symbolically. It is usually said that a literary symbol stands for some ideas as it is just a convenient substitute for a fixed meaning. Symbols present an abstract idea through more concreate means. It is also an element of a work used to suggest something else. Within a given culture, somethings are understood to be symbols. In some culture, river is symbol of time whereas the journey is the symbol of life.

\section{Conclusion}

In this way, symbol is defined with its background. Moreover, the preromantic poet William Blake has used so many different kinds of symbols. The Tyger which is an extremely symbolic poem is 
very unique. Thus, the symbol in his poetry is more often its own starting point, not the end but the beginning of the process. He has used the symbols to evoke world. The symbol in his hand became a true metaphor which has evoked the world in terms of itself. Thus, almost every theory is symbolic in this symbolic poem. As his symbolic power attains maturity, the symbols as well gain intricacy, association, evocative quality and richness. Symbolism seems to have enabled him to make his vision concrete and substantial. The pictorial presentations of vague, fleeting sensations and experience have been possibly only through symbols. It has helped him to express deeper reality something mystical in essence. The major theme of the poem is that human beings have two tendencies: the tendency of the gentle lamb in their faith and obedience to the ideal and true, and the terrible force of rebellion and revolution against the oppression and domination. Therefore, every individual revolts against the artificial system of society that darkens the natural brilliance of spirit and intelligence.
If there is no truth, justice, naturalness and order in the society, every individual is compelled to fight against false beliefs, teachings, traditions and laws in favour of the corrupted powerful traditional people of the society. The conventional sources of power that controls the society are always scared of the free thinkers, the revolutionary, the imaginary artist, the visionary and the true poet. God is mysterious and unknowable. Even if, he has given human beings not only the gentleness of the lamb but also the force of tyger. It is concluded that a person has to pass through an innocent state of being, like that of the lamb, and also absorbs the contrasting conditions of experience, like those of the tiger, in order to reach a higher level of consciousness. In any case, poet's vision of a creative force in the universe making a balance of innocence and experience is at the heart of this poem. In this way, the poet has used different kinds of words or objects as symbols so that it is concluded and proved that there are a lot of symbols used in his poem Tyger. Thus, the poem Tyger has been justified as a symbolic poem.

\section{Reference}

Abrams, M.H and Geoffrey Galt Harpham (2009). A Handbook of Literary Terms; 9th ed. United Kingdom: Thomson

Baldick, Chris (2012). Oxford Dictionary of Literary terms. 5th ed. United Kingdom: Oxford University Press. Ferguson, Margaret and Mary Jo Salter (1995). The Norton Anthology of poetry. 4th ed. California: U.F.C. Murfin, Ross and Supriya M. Ray (1997). The Bedford Glossary of critical literacy terms. 1st ed. North America: Bedford Book Publisher.

Penguin (2011). Dictionary of Literary Terms and Literary Theory. 8th ed. London: Penguin books Ltd. 